\title{
Social Meaning and Social Norms
}

\section{Citation}

Lawrence Lessig, Social Meaning and Social Norms, 144 U. Pa. L. Rev. 2181 (1996).

\section{Published Version}

http://scholarship.law.upenn.edu/penn_law_review/vol144/iss5/16/

\section{Permanent link}

http://nrs.harvard.edu/urn-3:HUL.InstRepos:12942289

\section{Terms of Use}

This article was downloaded from Harvard University's DASH repository, and is made available under the terms and conditions applicable to Other Posted Material, as set forth at http:// nrs.harvard.edu/urn-3:HUL.InstRepos:dash.current.terms-of-use\#LAA

\section{Share Your Story}

The Harvard community has made this article openly available.

Please share how this access benefits you. Submit a story.

\section{Accessibility}




\section{LAWRENCE LESSIG†}

The virtue of economics is its economy. Its sparse ontology. Its simplicity. With a few blocks, it aims to build the world. And with a few blocks, it has built much. Becker-ized or Posner-ized, economics has given insight into the full range of human life, with very few conceptual tools. There have been critics: those who complain that too much is missed; that the reduction is not without loss; that what is essential has been lost. But in large measure, these complaints miss the mark. One does not mind pocket-sized maps, so long as they guide reasonably well.

Sometimes they do not. Sometimes this sparseness and simplicity make one miss something important. New blocks are then needed. Some see these gaps as pathology-evincing a rotten core in economics's foundations. But economics does not need a foundation; we need not worry whether we can describe its core. When Russell pointed out the flaw in Frege's derivation of the foundations to mathematics, the math curriculum in elementary schools did not change much. Arithmetic goes on perfectly well without foundations. Economics can as well. ${ }^{1}$

Gaps do invite something more, however, and this push suggests two kinds of supplement. One is the supplement of Posner: small additions to the core ontology, deployed to pragmatic ends. ${ }^{2}$ The other is the supplements of Elster or Hardin: large additions to this core ontology; whole new classes of stuff; social norms, for example, that supplement talk of individual preferences as a way to understand behavior that does not quite fit talk limited to individual

† Professor of Law, University of Chicago Law School. Funding provided by the Russell Baker Scholars Fund and the Sarah Scaife Foundation. Thanks to Judge Richard Posner for comments on an earlier draft.

'One might think that this rejection of foundations is unprincipled lawyers' ad hocery. If so, this thought will only grow over the next few pages, because my argument in the end is that economics should add meaning speak to its basic ontology set, and one might well argue that epistemically, talk about meaning is inconsistent with the foundations of economics. Indeed it is. But my claim, again, is that there is value in using the tools of economics, even if the domain over which they are used lies outside of economics's core domain. Or at least, we should see if there is such a value. Or at least again, talk of philosophical foundations should not stop us in that search.

${ }^{2}$ See RICHARD A. POSNER, Aginc AND Old Age 84-94 (1995) (discussing multipleselves). 
preferences. $^{3}$ The articles of this Symposium are in the tradition of this second supplement. They aim to work out social norm talk, consistent with the tradition of economics or rational choice that they inherit. ${ }^{4}$ The aim is compatibility-the effort to show that this richer ontology is consistent with the sparseness of the old. The technique is to link the new methods with the old.

This is also the focus of the two articles that I was asked to review for this Symposium. Dennis Chong's article, especially, is an effort to help the old school along. In its breadth, it offers comfort to the old school, for it sketches how an extraordinary range of otherwise "non-economic" phenomena might nonetheless fit an economic account. ${ }^{5}$ Richard Hasen's article is more targeted: It picks one puzzle for the classical theory (why people vote) and shows how this richer ontology might solve this puzzle. ${ }^{6}$ In both cases, the suggestion is that we can be excused for adding social norm talk to the account, because the norm talk will advance our understanding of human behavior, without rejecting what went before.

I have nothing against this respect for (intellectual) elders. Economics has a tradition one ought to respect. But I am a lawyer, and lawyers have few respectable elders. Law is not a science, and in the main, our elders are a generation who proclaimed that there were no elders. Lawyers are intellectual orphans.

The orphan has a freedom that the child does not, and it is from this position of relative freedom that I want to argue that something more will be needed here. This supplemental norm talk is a nice first move, but it will not be enough. We will not understand the phenomena upon which this Symposium focuses, and more importantly, we will not know how to regulate it, until we add yet another block to this ontology. It is not enough to talk about social norms. We must also speak of social meaning.

The argument for meaning talk is this: Norm talk is behaviorfocused. It asks what a community does. It shares with its frugal father economics the desire to just observe behavior, without the need to understand it. The perspective is external, and from this

'See, e.g., JON ELSTER, THE CEMENT OF SOCIETY $97-152$ (1989); RuSSELl HARDIN, COLLECTIVE ACTION 155-228 (1982). My point is not that these authors invented norm talk; the centrality of norm talk in their work is what marks its significance.

4 I will speak of economics and rational choice theory interchangeably, although I mean by the former what most commentators think of as the latter.

${ }^{3}$ See Dennis Chong, Values Versus Interests in the Explanation of Social Conflict, 144 U. PA. L. REV. 2079 (1996).

${ }^{6}$ See Richard L. Hasen, Voting Without Law?, 144 U. PA. L. REV. 2135 (1996). 
external perspective, it describes prices, or costs associated with deviating from this regularity. Ordinary behavior is thought to be cheapest; deviance costly.

As a first cut, this methodology is not bad. It is just crude. It tries to locate a cost associated with behaviors; but the determinants of that cost are too simple, or incomplete. Norm talk accounts for behavior; it does not discipline itself to account for context. It does not focus on the relation of behavior to context and the differences that relation raises.

An example illustrates the point. In 1856, Preston Brooks caned Charles Sumner on the floor of the U.S. Senate. ${ }^{7}$ Social norm talk might speak of the costs this caning created. There is a fairly solid anti-battering norm in most civilized societies. Sumner suffered the costs of being battered; Brooks suffered the costs of being a batterer. Norm talk might calibrate the harm to Sumner according to the harm that any victim of a mugging might suffer.

But the costs of this action-raising a cane and battering another with it-have only a slight relation to the costs of a mugging. What was significant in the caning was not the deviation from a norm against battery. Its significance was its meaning. Caning was how a master treated a slave; it expressed the presumption that the social status of the victim was below the social status of the attacker. Caning expressed something by the very choice of weapons used, in the same way that a challenge to a duel would have. A challenge to duel would have meant that the challenger considered the challenged either his equal or his superior. The challenge to duel would have expressed this respect. Depending upon the balance of the social context, it is plausible that the victim of a caning is worse off than the wounded victim of a duel: the victim of a duel suffers only the risk of corporal injury, whereas the victim of a caning suffers certain social injury as well.

Norm talk misses this distinction. The price of caning is a function of the action and the contextual understandings behind it. Norm talk focuses on the action and ignores the context. Meaning talk focuses on both. Norm talk speaks of the price of behaviors; meaning talk speaks of prices in particular contexts. Norm talk abstracts; meaning talk makes contingent. (1980).

7 The story is well told in JACK K. WILliams, Dueling IN THE OLd SOUTH 26 
I am speaking in general. My point is about the average, not about every case. There are those who use the language of norms in a way that is indistinguishable from what I mean by meaning, ${ }^{8}$ and there are those who use the language of meaning in ways just as crude as norms speak. But my argument is not about reporting how people speak; it is about recommending how we should speak. We should allow norm talk to be thin and foreground-focused, and we should use meaning talk to speak of the salience that particular norms have within a given social context. The argument is not critical of norm speak, but it presses for something more. It is about the value of an interpretive turn in economics;. about the returns that this investment might bring.

The return is of two sorts. One is descriptive, the other, prescriptive. The descriptive return is revealed in what norm talk tends to miss. The examples are many, but one from each of these two articles might suffice. Begin with Dennis Chong: Chong describes the pathology of Senator Packwood. A practice or discipline in Packwood's life-learned to overcome shyness-led him to a habit of behavior-gregariousness laced with bawdiness-which, when the world changed, he could not easily give up. ${ }^{9}$ That is interesting, plausible, and sad, but what is troubling is the next move. Chong likens Packwood's dilemma to the problem faced by inner-city youths who, because of "the clothes they wear, the language they use, and the way they move[,] ... have trouble adjusting to the norms of 'decent' behavior required at school and on the job." 10

But this does not follow, and we can see why from the perspective of meaning. Packwood got himself stuck in a kind of behavior that he could not change, a habit that he might regret. The innercity youth does not face this sort of rut. The inner-city youth's problem is not that he has a habit of behaving "indecently" that he just cannot shake. Rather, the problem is that "decency" changes

${ }^{8}$ See, e.g., Peter H. Huang \& Ho-Mou Wu, More Order Without More Law: A Theory of Social Norms and Organizational Cultures, 10 J.L. ECON. \& ORCANIZATION 390, 391 (1994) (arguing that the scope of law and economics can be expanded by incorporating the role of emotions into the study of how social order can be maintained without further law). Their use of norm talk is close to what I mean by meaning talk.

${ }^{9}$ See Chong, supra note 5, at 2084 ("The irony in Packwood's case is that times have changed and relationships between the sexes in and out of the workplace have been redefined, but unfortunately the traits that Packwood so deliberately learned to smooth his path continue to rule him like an addiction, prompting behavior that is no longer tolerated.").

${ }^{10} \mathrm{Id}$. at 2084-85. 
between these two very different social contexts and the youth does not quite know who he is, or who he wants to be, in the mainstream culture. This is a crisis of meaning, not inertia.

A similar point can be drawn from Ricgard Hasen's article. Hasen describes the "snowball effect" that might occur as more and more people violate a norm. What explains the snowball effect is that there are "decreasing odds" of being punished, and therefore individuals increasingly refuse to behave according to the norm. ${ }^{11}$ Tax evasion might be an example. ${ }^{12}$ When tax evasion is low, the likelihood of punishment might be high; but as evasion increases, there are, Hasen might argue, decreasing odds that one would be caught.

As Dan Kahan has argued, however, this account misses something of the dynamic in the snowball effect. ${ }^{13}$ For the trend is not continuous; at a certain stage, norm-violating behavior jumps. To account for this jump, meaning talk is needed.

- The meaning account might proceed like this: While everyone is obeying a certain norm, the meaning of obeying that norm is simply conformity. Conforming when everyone else is conforming is often an individual good: One is doing what others are doing; one is behaving appropriately. When norm violation increases, however, the meaning of obeying the norm changes. At some point, when everyone else is violating a norm-when everyone else is evading their taxes-obeying the norm makes one a "chump." It is no longer the case that the pressure to obey the norm has been lessened solely because of the decreasing odds of being caught for violating the norm. Now there is an affirmative cost to obeying the norm as well. This shift would account for a jump in the normviolating behavior in a way that the "decreasing odds" account would not.

In both cases, norm talk leaves something out. Meaning talk reveals something more about the contours to the costs of the different behaviors; it imports a language that can understand discontinuities in the valuation of similar behavior. Meaning talk understands price relative to context; norm talk does not. Put

"See Hasen, supra note 6, at 2151.

${ }^{12}$ See, e.g., J.C. Baldry, Tax Evasion Is Not a Gamble, 22 ECON. LeTTERs 333 (1986) (describing the discontinuity caused by "moral notions" in tax-compliance behavior).

${ }^{13}$ See Dan M. Kahan, Social Influence, Social Meaning, and Deterrence 7-8, 15-16, 20-21 (Apr. 2, 1996) (unpublished manuscript, on file with the author) (describing the social meaning and social influence effects in criminal regulation). 
another way, norm talk speaks of nominal prices, where meaning talk speaks of real prices.

The real advantage to meaning talk, however, is prescriptive. When one is norm-focused, the idea of changing a social norm appears extremely difficult. The rhetoric is always about "evolving customs" and the slow rate of behavioral change. The picture is one of exhorting a group to act differently, and the sense is always of some blob that must be pushed from all sides if it is to be moved at all.

It might be that a particular norm is impervious to change. Social structures are differentially plastic, and norms are part of social structures. But whether a norm is difficult to change depends upon more than mere inertia. As the examples above suggest, it depends as well upon the cost or the price of continuing to engage that norm. To speak of these prices, however, requires meaning talk, and meaning talk might in turn cue us to better ways to rẹgulate social norms.

Two examples will make the point. The first is drawn from the history of techniques used to regulate dueling. ${ }^{14}$ Dueling was a norm of the elite, in America as in Europe. At some point in both contexts, there was political resolve to eliminate the practice. Compare two techniques for eliminating the practice: prohibiting dueling and disqualifying people who have dueled from holding public office.

Both techniques increase the cost of dueling; and in the abstract, or rather, abstracted from the particular social context of dueling, one might think that the first is more costly than the second. But a meaning account suggests something different. When challenged to a duel, the gentleman rightfully challenged is called upon to put himself at great risk in the name of defending his honor before the community. ${ }^{15}$ The first regulation just increases the expected harm of that challenge. Now the expected harm includes some (perhaps slight) chance that the person accepting the challenge will also suffer the costs of jail. That no doubt is a significant cost, but it is no different in kind from, say, the increased expected costs due to more accurate weapons. These are personal costs that the challenged might bear to defend his honor in the community.

14 I discuss this point in greater detail in Lawrence Lessig, The Regulation of Social Meaning, 62 U. CHI. L. REv. 943, 968-73 (1995).

${ }^{15}$ Note that the additional costs of the sanction are imposed only upon conviction, which itself is a low probability event. 
The second technique functions somewhat differently. As well as the duty to defend one's honor, a gentleman has a duty to serve his community. Dueling conflicts with that second public duty, and the refusal to duel now has a plausible public-regarding reason associated with it. With the first technique, refusing a challenge simply means one is a coward; with the second technique, it is ambiguous whether one refuses the duel because one is a coward or because one is serving a second, and competing, public duty.

The second technique ambiguates the social meaning of refusing a challenge; the first technique does not. The second technique creates (or can create) a plausible claim that the reason one refuses the duel is public-regarding, rather than merely self-regarding. Ambiguation thus reduces the social meaning cost of refusing a challenge, and it does this by mucking about with the context within which such a refusal would be made. Only an account that focused upon this context could understand the contours that this development presents.

The second example of the prescriptive advantage of meaning talk uses the opposite technique. Rather than ambiguating the social meaning of a particular act, this example tries to reduce the ambiguity in the social meaning of a particular act. Kahan again supplies an example.

Kahan notes the increasingly frequent use of imprisonment as a technique of punishment. ${ }^{16}$ This, as economists have long noted, is odd. It is odd because many of these offenses could be punished more cheaply by fines rather than imprisonment. Imprisonment is both costly to society and costly to the individual. For those with assets, fines could be set that would create equivalent deterrence, but with nothing comparable to the equivalent cost. So why the move to imprisonment?

Kahan's answer relies on an ambiguity in the social meaning of fines. Fines can be viewed both as punishments and also as prices. They can, that is, be seen both as condemnatory, and also as simply the price a defendant must pay to engage in a certain activity. ${ }^{17}$

${ }^{16}$ See Dan M. Kahan, What Do Alternative Sanctions Mean?, 63 U. CHI. L. Rev. (forthcoming Spring 1996) (manuscript at 593, 607) (noting that "[i]mprisonment is the punishment of choice in American jurisdictions" and that "[a] decade of significant reform has not lessened the dependence of American jurisdictions on imprisonment").

${ }^{17}$ See id. (manuscript at 622) (stating that fines "are politically unacceptable not because the public perceives that they are insufficiently severe, but because it believes that fines are insufficiently expressive of condemnation"). 
This ambiguity is costly for the criminal justice system. It is costly because it reduces the usefulness of fines. ${ }^{18}$ If fines were unambiguously condemnatory, then the political system could impose them without the fear that they would be viewed as something other than condemnation. To the extent that their meaning is ambiguous, however, the political cost of using fines as punishment is high.

Kahan's solution is to change the meanings of a fine; his technique is tying. By tying the fine to some other unambiguously condemnatory punishment, one reduces on the margin the ambiguity in fining and thereby increases the availability of fining. For example, by tying the fine to a small amount of imprisonment, or alternatively some shaming punishment, the ambiguity in the meaning of fining is reduced. ${ }^{19}$

In both the dueling and fining example, the meaning perspective adds a technique for changing the costs associated with certain behaviors by altering the interpretive context within which those behaviors exist. Price is always a function of context. Meaning talk simply points to the techniques for changing context that might change the cost of behaviors within that context. Ambiguation changes the cost by making it unclear just what meaning an action has. Tying changes the cost by making it more clear just what meaning an action has. ${ }^{20}$ This focus on context is what norm talk cannot easily add.

Of course, meaning talk is not cheap, at least epistemically. One cannot use meaning talk to speak in ways that purport to be general laws of humanity. Meaning prescriptions, and descriptions, are more local, more contingent. Meanings are often highly contestable ${ }^{21}$ and sometimes hard to know.

${ }^{18}$ See id. (manuscript at 623) (arguing that if a fine is not viewed as a sanction that invariably condemns, like imprisonment, but rather is viewed as a price, then "a fine, no matter how large, won't be viewed as an adequate substitute for an appropriate term of imprisonment ${ }^{n}$ ).

${ }^{19}$ See id. (manuscript at 655).

${ }^{20}$ For a further discussion of these two techniques, see Lessig, supra note 14, at 1009-12. Jack Balkin suggests that the techniques of tying and ambiguation exist within a nested opposition-that we might see each as the inverse of the other. See J.M. Balkin, Nested Oppositions, 99 YALE L.J. 1669, 1696-1704 (1990) (book review) (pointing out that essentialism defines nested opposition). This is correct.

${ }^{21}$ This, for example, was Ronald Dworkin's view of Michael Walzer's use of social meaning talk. See Ronald Dworkin, To Each His Own, N.Y. REv. Books, Apr. 14, 1983, at 4, 4 (reviewing Michael Walzer, Spheres of Justice: A Defense of PLURALISM AND EQUALITY (1983)) (arguing that Walzer's theory fails because "[i]t tells us to look to social conventions to discover the appropriate principles of distribution for particular goods, but the very fact that we debate about what justice requires . . . 
My argument, however, is about value, not cost. The argument is that there is a positive return from meaning talk, not that one can engage it at a zero price. The claim is that something is missed, both descriptively and prescriptively, without meaning talk, and that some of what is missed might be gained with it. The claim is comparative, not absolute.

The consequence may be a limit in generality. But if one consequence of engaging meaning talk is a greater humility in economics-speak generally, who is to say this would be so bad? It might well be that resistance to economics-speak generally comes from this air of imperialism. ${ }^{22}$ A meaning manager might suggest tying the message to something less grand: giving up a bit of the drama, aspiring less to what seem like laws of nature, and acknowledging pragmatism as the only foundation. All this may change the meaning of economics-speak and thereby reduce the cost of engaging it in law. Or so some might think, and others recommend. 
